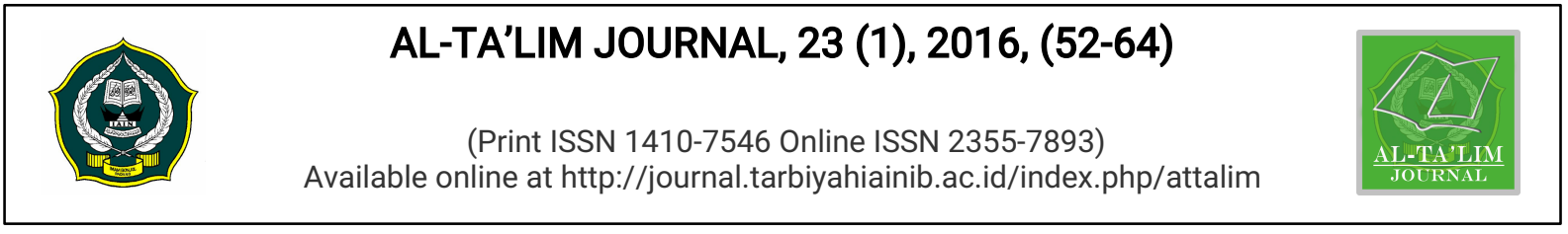

\title{
The Influence of Principals' Leadership Styles on School Innovation in Jambi (Case Study in Several Senior High Schools in Jambi)
}

\author{
Samsu' \\ Department of Islamic Education, Faculty of Isamic Education and Teacher Training \\ IAIN Sulthan Thaha Saifuddin Jambi, Indonesia \\ 1E-mail : samsu.su@yahoo.co.id \\ Rusmini \\ Department of Islamic Education, Faculty of Isamic Education and Teacher Training \\ IAIN Sulthan Thaha Saifuddin Jambi, Indonesia \\ E-mail : rusmini78@yahoo.co.id
}

Received: $17^{\text {th }}$ December 2015; Revised: $04^{\text {th }}$ January 2016; Accepted: $27^{\text {th }}$ February 2016

\begin{abstract}
School leadership styles that affect school innovation is essential to bring schools' changes. This study aimed to determine school leadership styles and its effect on school innovation at the senior high school level in Jambi city. This study uses ten leadership styles, they are participative, laissez faire, authoritarian, democratic, charismatic, transformational, situational, trust, grid, and threedimensional leaderships. The framework of the research are developed by associating ten leadership styles with school innovations including (1) the principal's role in doing innovation in the schools, (2) the forms of innovation implemented in the areas of academic achievement, (3) the form of innovations carried out in the field sports and (4) the form of innovations implemented in the institutional field, and (5) the forms of innovation undertaken in the field of school' culture. There are 32 teachers and 32 principals were taken as samples. This study used mixed methods research. Data were analyzed using mean, standard deviation, and correlation. The results showed that the overall principal's leadership style is not sufficient to affect senior high school innovation in Jambi city, this is evidenced by there are only three of those ten leadership styles have positive relationship when they are doing school's innovations in Jambi city. Thus, the principals should give attention to all the leadership styles to do innovation at senior high school in Jambi city to improve the quality of schools.
\end{abstract}

Keywords: Leadership styles, principals, and schools innovations

How to Cite: Samsu, S., \& Rusmini, R. (2016). The Influence of Principals' Leadership Styles on School Innovation in Jambi: Case Study in Several Senior High Schools in Jambi. Al-Ta Lim Journal, 23(1). doi: http://dx.doi.org/10.15548/jt.v23i1.154

Permalink/DOI: http://dx.doi.org/10.15548/jt.v23i1.154 


\section{INTRODUCTION}

School's principals have very important role in realizing the schools' innovations. One important factor that can influence innovation in schools is the principal's leadership style. Principal's leadership style which is liked by teachers and other subordinates will create an atmosphere that will be conducive to realize the school innovations. The closeness between the principals with teachers and other subordinates is a good relationship that help principals and teachers in performing their duties at the school (Mangkunegara, 2011). Without good leadership style, the school is only a stagnant community. Therefore, every school should have a good leadership style. The role of school leadership style will affects schools and somehow will be the characteristics the school. Therefore, any principals need to design themselves in such a way in order to realize his or her willingness to be an ideal leader.

Leadership is defined as the ability and skill of a person who served as leader to influence the behavior of others, especially subordinates, to think and act in such a way that through positive behavior, he gives real contribution in achieving the school goals (Rivai and Murni, 2009). The role of leaders as agents of change is one that needs to be developed to improve the quality of school services. Quality of school service is determined by how a leader perform their duties and how he or she affect their subordinates to work properly in accordance with what is desired to achieve the school goals.

Based on the theory that has been mentioned, leadership can be defined as the ability to influence all the followers or subordinates in order to do the job with cooperation and mutual support for achieving the purpose. Because of that, to be a leader needs high loyalty and always provide the best for the subordinates.

Every person (principal), have a "style" in directing subordinates, but because principal's leadership style affects schools greatly then the leadership style needs to get serious attention in the school. Leadership style is related to how to influence subordinates and to deliver and to implement his ideas and how leaders give or delegate trust and authorities to his subordinates (Getol, 2012). Therefore, the leadership behavior shown in the managerial process consistently called leadership style. The leadership style is how to behave typical of a leader to his subordinates. Thus the leadership style is the way how the leaders behave consistently with the employee as a member of the group (Wahyudi, 2009). One of the leadership styles that are favored by the teacher is democratic. Democratic means teachers are given freedom to express ideas and use deliberation to reach compromise.

It is inevitable that in organizing education in the school, the school would need a leader who could be invited to communicate, interact, and take a policy based on mutual understanding and discussion. Principal's style of leadership style needs to be developed in schools, especially in making them able to communicate, interact and take the policy, because the teachers and administrative staff needs a harmonious relationship between leaders and subordinates in carrying out daily duties in school. Therefore, in this study it is important to see the school leadership style, and influence of principals' leadership style on the schools innovation, especially in Jambi city. 
In addition, several other thinkers provide a definition of leadership style and among others is for example Tofan Agung Eka P (2009) that leadership style can be defined as a special appearance or characteristics of a leadership. Leadership style is an important factor in running leadership effectiveness. In organizations, leadership style application means that someone able to influence the attitudes and behavior of their subordinates (employees) so they can do their job well. Leadership in an organization occurs because there is an interaction between the three important components of an organization: leaders, subordinates and the situation or certain working conditions.

\section{The Importance of Leadership Style}

Style is a nature, character or propensity of a leader in the lead or the use of power and policies in an organization. Style of a leader in leading, generally differ from one another depending on the nature, character and tendencies or situation facing a leader in the lead. Samsu (2014) has explained that in Indonesian context, crysis of uswatun hasanah (social trust) has occured in this time, it will cause the nation is lost of leadership figure that he/she can be referenced in all life and leadership aspects. It is because leadership and how to know the leadership style is important.

\section{The Leadership Style of Principals in Jambi city}

The school principal is the most important person at the unit level of education (schools), because of its role as a leader, manager and school administrators. The school principal is the highest position at the senior high school level, appointed by the Provincial
Education Department, as well as responsible for what is happening in the school and its surroundings.

The leadership style of a leader must be adapted to the situation, the nature and behavior of the people being led. Therefore, be an effective leader, one must not only embrace a leadership style only, but the leader must be flexible to choose a style of leadership that is otherwise deemed appropriate for the purposes of the organization.

To be an effective leader not only they have to adopt a certain style of leadership but they should be combine one leadership style with another. Each leadership style has advantages and disadvantages of each. So it is difficult to determine which leadership style is the best, that's combining them is a must.

The most important thing is that a leader should intelligently determine what leadership style should be applied in circumstances being faced in the organization or a leader. Sometimes because if a leader only uses one style of leadership it would makes some subordinates feels that the leader not able to solve all problems, only certain problems. Yet it is precisely in certain circumstances (perhaps are urgent or critical) that certain leadership style is useful for the organization. The dilemma is that not every leader can change their leadership styles to suit certain situations or problems, while the change of leadership styles in order to suit every problems is important to sustain the organization and gain supports from the subordinates.

Principal leadership style in Jambi city now is more oriented on the individual 
style of each principal, not systemic and organizationally. As a result, individual schools cannot be detected using what leadership style. In practice, this proves that the innovative school is highly dependent on owned principal. In the event of school principal rotation, the school will have an impact on innovation. Though a good school must continue to do innovate school in order to the quality of school management can be realized well.

\section{Innovation School}

Today the term innovation in organizational life increasingly becomes important, because each person basically cannot escape from the life of the organization. Prescott W, \& Hoyle $E$ as quoted by Hasibuan (2004) states that innovation can be understood in a double sense. Firstly, the meaning seen in the form of common noun is: "a new object, idea or practice". Secondly, as an abstract noun, namely: "a process in which an idea, object or new practices raised to the surface and was adopted by individuals or groups".

This process start from the findings (invention) followed by the development process, and the process of adoption". Innovation is one of the words that are often used in leadership, innovation and leadership even very well aligned. Leadership always has some focus to realize a better future. In this case, the leader is always innovative.

The issues of innovation in organizational life are inseparable from the four kinds of factors, namely 1) innovators are referred to as agents of change, 2) the innovation itself, 3) people or institutions that adopt innovations, and 4) the innovation process itself takes many time (Harris, Lown, \& Presscott w, (Ed) in Lias Hasibuan, 2004). Each one of these factors is described by Hasibuan (2004) as follows.

\section{1) Agent of change}

Innovators can be defined as a person or certain parties who bore/bring innovation, namely in the form of new ideas or practices. Based on studies Rogers noted that the group of innovator as shown in the frequency distribution table was only around $2.5 \%$ only (Rogers in Lias Hasibuan, 2004). This shows that the so-called groups of innovators are not many in number. Further Hasibuan explained that we can understand the limitation of the number or group of innovators, resulting in ideas and new practices only a few who understand it. The existence of these limitations requires innovators to disseminate ideas and new practices into the social value system. This socialization requires the wisdom of innovators, if it is not; ideas and new practices often find failures in the process of adoption.

2) Innovation

Rogers in Hasibuan (2004) reveals that there are five characteristics of innovation that determines the success of the innovation itself. The fifth of these characteristics are: (a) the relative advantage derived from an innovation, (b) Compliance innovation with the values and social norms that exist on the adopter, (c) Innovation must be tested, (d) The complexity of the innovation, (e) Innovation can be seen by prospective adopter innovation.

3) Persons or institutions that adopt innovations

An innovation can be adopted by individuals or institutions (groups). The adoption process should ultimately bring the institutionalization of new elements into the life system of individuals or 
groups (institutionalized).

4) The process of innovation

The innovation process takes place in four stages, namely invention, development, diffusion and adoption. At this stage of the invention, the process of innovation requires innovators that the inventor to give birth to an idea or new practices. At this level innovator (inventor) is defined as the dynamic personal creative, even controversial to come up with ideas or new practices.

There are several factors that facilitate or impede innovation, to identify factors that regulate positive and negative results of innovation for individuals and groups when they take the risk to be involved in innovative activities. First is the behavior of the innovation. It is require a wide range of cognitive and socio-political efforts and investments which may lead to success or failure, high or low performance in the execution of duty, conflict, positive or negative work attitude and high or low levels of well-being, Second is skills and attitudes of employees are innovative. Cognitive and interpersonal skills, a willingness to discuss and resolve disputes will facilitate innovation and reduce the occurrence of conflict. Third is the process group of coworkers in the team. Innovation is rarely the result of one individual activity, cooperation is very important. The right team knowledge, skills and abilities will affect the process of the group, including conflict management skills, collaborative problem-solving skills, communication skills, goal setting and performance assessment skills. The effectiveness of the group will be enhanced with the clarity and commitment to common goals and participation in decision-making. Diversity group and team ownership are two characteristics of the team that should support innovation positive results. Fourth is leadership style. Innovators need the autonomy of the rules and procedures of the organization. Participation and direct support will stimulate the behavior of innovative work, which is participative leadership that would imply the existence of consultation and delegation, as well as support relating to the recognition and provision of resources to innovate, and the fifth, the organizational context also affects the results of the behavior of innovative work. It can be considered negative if it impede innovation occurs, or positive if it can promote a culture of innovation.

Support for changing, focus on customers (stakeholders) and organizational learning are the three characteristics of organizational context that contributes to a culture of innovation. Support for change is crucial in the face of potential conflicts arising from the innovation.

In this article, there are ten styles of leadership that will be examined, namely: 1) participative, 2) laissez faire, 3) authoritarian, 4) democratic, 5) charismatic, 6) transformational, 7) situational, 8) trust, 9) grid, and 10) threedimensional leadership styles.

\section{Research purposes}

Investigating leadership styles which are used by principals in Jambi city will provide a real feedback to this form of innovation that run the principal at their respective schools. This article will examine the problems posed by the condition of innovation leadership style of the principal. In other words, this study will 
highlight about the leadership style which is practiced by the principals in Jambi city. Therefore, this article seeks to answer the following questions 1 ) What is the style of principal leadership in senior high school in Jambi city? 2) How does innovation happen in senior high school in Jambi city during this time?, and 3) Is there a significant difference between the school leadership style to innovation senior high school in Jambi city?

\section{METHOD}

This article used mixed methods approach, the quantitative data as the main data, while qualitative data as supporting data to explain the findings of existing research, so that each of the data will be analyzed and to be the results of research (Creswell and Clark, 2007). The type of data that was used in the form of information obtained through observation, interview, and questionnaire. As for the data source to obtain the necessary information in this article consisted of principals as leaders and teachers at senior high school in Jambi city.

There were 32 senior high school in Jambi city be used as a location for research, namely: 1) SMA Negeri 1 Jambi city, 2) SMA Negeri 2 Jambi city, 3) SMAN 3 Jambi city, 4) SMAN 4 Jambi city, 5) SMAN 5 Jambi city, 6) SMAN 6 Jambi city, 7) MAN Model Jambi city, 8) MAN 2 Sebrang of Jambi city, 9) MAS Nurul Falah Jambi city, 10) MAS Mahdaliyah Jambi city, 11) MAL Jambi city, 12) SMA 7 Jambi city, 13) SMA 8 Jambi city, 14) SMA Negeri 9 Jambi city, 15) SMA Negeri 10 Jambi city, 16) MAS Al-Khoiriyah Jambi city, 17) MAS As'ad Olak Kemang, 18) MAS Nurul Ihsan Muhajirin, 19) SMA GUPPI Jambi city, 20) SMA 11 Jambi city, 21) SMA Ferdi Ferry Jambi city, 22) SMA Pertiwi Jambi city, 23) SMA At-Taufik
Jambi city, 24) SMA Nurussholah Jambi City, 25 ) SMK Negeri 1 Jambi city, 26) SMK Yadika Jambi city, 27) SMA Nusantara Jambi city, 28) SMA IX Lurah Jambi city, 29) SMA Adhiyaksa Jambi city, 30) SMA 2 Mei Jambi city, 31) SMA Baiturrahim Jambi city and 32) SMA AlFalah Jambi city.

The total population of teachers who studied to provide a response to the principal's leadership style in relation to innovation school was 32 people. Each teacher was consulted through a questionnaire to see the leadership style employed by their school principals respectively, while the total sample used as many as 64 people consisting of 32 teachers and 32 principals; spread on a senior high school in Jambi city. To obtain qualitative data also interviewed principals as leaders in their respective to senior high school. Selection was done through stratified random sampling. According to Chua (2006) selecting through a stratified random sampling means doing it in isolation, in this case the teachers and principals of existing and selected as samples.

\section{Technique of Data Collection}

The process of collecting and analyzing data is an important step to guarantee the success or failure of research. In this study, the main information was information obtained directly from the sample through a circular questionnaire, which itself was based on the perception of respondents answered. Researcher used questionnaire, interview, observation and documentation in collecting data.

\section{Data Analysis}

Data analysis is the process of categorization, organization, manipulation, and summarizing data to obtain answers to questions research (Kerlinger, 1998). 
Data analysis performed in this study had two shades of analysis, ie analyzing the time to sharpen the validity of data, and analysis through the interpretation of the overall data.

\section{Quantitative Data Analysis}

Quantitative data analysis was
performed through quantitative
descriptive analysis, meaning the entire
sheet questionnaire examined one by one
and then every choice of respondents
researched and summed to look for a
percentage. Score assessment was
carried out through a Likert scale.

The quantitative data analysis was done first followed by the analysis of qualitative data to give more meaning to the principal's leadership style (senior high school) in Jambi city. Following the opinion of Sambas (2007) analysis of statistical data which was used in this study was descriptive statistical data analysis and inference. Descriptive statistical data analysis that is normally used is the percentage of data presentation, frequency, mean, standard deviation, median or mode. Therefore, in this descriptive data analysis, data presentation which was done was through the mean and standard deviation, while the inference statistical data analysis to analyze the data using Pearson correlation and linear regression. The purpose of descriptive analysis and statistical inference was to generate inference and generalization of the research findings. The questionnaire data were analyzed by means of encoding and inserting it into the computer. Data for the principal's leadership style scores in Jambi city also entered into a computer for analysis. Software Statistical Package for Social Science (SPSS) version 12.0 was used to analyze the data.

Descriptive analysis which outlined the overall status of the study population that aims to provide a preliminary description of the profile of the respondents was senior high school teachers throughout Jambi city. Statistics used were frequency and percentage. Descriptive statistics also outlined the variables of school innovation. Statistics used were mean, standard deviation. Interpretation mean scores used were as in table 1 below:

Table 1. Interpretation Score Mean

\begin{tabular}{cc}
\hline Mean Score & Interpretation \\
\hline $1.00-1.79$ & Very low \\
$1.80-2.59$ & Low \\
$2.60-3.39$ & Medium \\
$3.40-4.19$ & High \\
$4.20-5.00$ & Very high \\
\hline \multicolumn{2}{l}{ Source: Sambas \& Maman (2007). }
\end{tabular}

Mean scores interpretation which was made by the interpretation made by Sambas and Maman (2007). According to them scores mean 4.20 - 5.00 shows respondents agree at this stage is very high, scores mean $3.40-4.19$ at the stage of high scores mean $2.60-3.39$ at the stage of medium, scores mean 1.80 2.59 at the stage of low and scores mean $1.00-1.79$ at the stage is very low on the principal leadership style (senior high school) in Jambi city, while the analysis of inference is used to see what relationships exist between the variables being studied is the dependent variable (the style of principal leadership) and independent variables (school innovation). The analysis used in this study are: (i) Pearson correlation analysis, and (ii) linear regression analysis. 


\section{RESEARCH FINDINGS AND DISCUSSIONS}

The research findings obtained to answer the problem formulation used in the study: 1) How does the principal's leadership style at senior high school in Jambi city? 2) How does innovation occurs at the senior high school in Jambi city during this time? and 3 ) Is there a significant difference between principal's leadership style of the senior high school innovation in Jambi city?

The first and second questions answered through statistical analysis of descriptive analysis to determine mean and standard deviation to see the stages of leadership style and innovation of existing school principals conducted by the leadership style studied. The third research question examined through inference that a correlation analysis to see the effect of the existing leadership style and executed by the principal.

\section{Profile of Respondents}

This section described the basic information about the background (profile respondent/ sample) selected overall by demographic factors (school, and gender) senior high school teachers in Jambi city, as outlined in table 2 below:

Table 2. Profile of Respondents/Sample Research

\begin{tabular}{ccc}
\hline Category & Sample & $\begin{array}{c}\text { Frequenc } \\
\mathbf{y}\end{array}$ \\
\hline Senior & Teacher & 32 \\
high & Principal & 32 \\
school & & \\
& Bachelor (S1) & 54 \\
Education & $\begin{array}{c}\text { Magister (S2) } \\
\text { Level }\end{array}$ & $\begin{array}{c}\text { Doctor/Ph.D } \\
\text { (S3) }\end{array}$ \\
& -
\end{tabular}

$\mathrm{N}=64$

The information in above table 2 showed the sample were 64 people who are grouped in two categories namely: (i) the teacher were 32 people and (ii) the principal as many as 32 people. From that number, 32 people serve in public schools and 32 people were dedicated at private senior high school in Jambi city. For the category of education there were as many as 54 teachers who had the educational background of undergraduate (S1), 10 people who had magister (S2) and no one doctoral background (S3).

In the following table also showed as many as six (6) principals selected to be interviewed to obtain qualitative data. From a total of six (6) people can be detailed each of the three (3) public school principals (senior high school) to be measured and three (3) private school principals interviewed to obtain data support or the truth about the research questions raised.

From thirty-two respondent principals were selected, the chosen three (3) the principal's public schools and three (3) private principal of senior high school with the reasons for choosing these respondents to be interviewed was because the principal was the party most responsible conduct the leadership and management of schools and many tasks related to development and the role of teachers in the schools.

Table 3. Profile of Respondents to Interviewed (Principal)

\begin{tabular}{ccc}
\hline Category & Sample & Frequency \\
\hline $\begin{array}{c}\text { Senior } \\
\text { high } \\
\text { school }\end{array}$ & Principal & 6 \\
$\begin{array}{c}\text { Education } \\
\text { Level }\end{array}$ & $\begin{array}{c}\text { Bachelor } \\
(\mathrm{S} 1)\end{array}$ & 1 \\
& $\begin{array}{c}\text { Magister } \\
\text { (S2) } \\
\text { Doctor/Ph.D } \\
(\mathrm{S} 3)\end{array}$ & 5 \\
\hline
\end{tabular}

$\mathrm{N}=32$

Principal Leadership Style In Senior High 


\section{School in Jambi City by Overall}

In this section we report the results of a descriptive study based on the scores mean and standard deviation of the 10 (ten) principals leadership style, they are: 1) participation, 2) laissez faire, 3) authoritarian, 4) democracy, 5) charismatic, 6) transformational, 7) situational, 8) trust, 9) grid, and 10) threedimensional. Principal leadership style variable studied based on the leadership style. There are 3 items each statement to explain about 10 principal leadership style. From the study showed the following results.

Table 4. Principal's Leadership Style at overall

\begin{tabular}{|c|c|c|c|}
\hline \multirow{2}{*}{ Leadership styles } & \multicolumn{3}{|c|}{ Senior High School in Jambi city } \\
\hline & Mean & SD & Interpretation \\
\hline 1) Participative & 4.19 & 0.69 & High \\
\hline 2) Laissez Faire & 3.46 & 0.97 & High \\
\hline 3) Autoritaran & 2.73 & 1.13 & Medium \\
\hline 4) Demokratic & 4.19 & 0.78 & High \\
\hline 5) Charismatic & 4.19 & 0.79 & High \\
\hline 6) Transformational & 4.18 & 0.69 & High \\
\hline 7) Situational & 3.90 & 0.73 & High \\
\hline 8) Trust & 4.36 & 0.58 & Very high \\
\hline 9) Grid & 4.06 & 0.65 & High \\
\hline 10) Three-Dimention & 3.48 & 0.83 & High \\
\hline Total & 3.87 & 0.78 & High \\
\hline
\end{tabular}

$\mathrm{SD}=$ Standard deviation

The information in table 4 showed that the senior high school leadership style as a whole in Jambi city were at high stages. Mean score senior high school principal's leadership style in Jambi city (mean $=3.87)$. Based on information obtained from table 4 it could be formulated that on the whole leadership style at the senior high school principal in Jambi city approved at the high stage.
The latest innovation happens at high school in Jambi city

The results showed that the innovation as the influence of the principal's leadership style that occurred at senior high school in Jambi city statistically (descriptive statistics) were in medium stages that can be described as follows:

Table 5. Senior High School Innovation at Jambi city 


\begin{tabular}{|c|c|c|c|}
\hline \multirow{2}{*}{$\begin{array}{l}\text { Senior High School Innovation } \\
\text { In Jambi city }\end{array}$} & \multicolumn{3}{|c|}{ During the time } \\
\hline & Mean & SD & Interpretation \\
\hline School principal to do innovate school & 3.25 & 0.43 & High \\
\hline $\begin{array}{l}\text { Your school principals attach great importance to } \\
\text { innovation in the field of academic achievement in } \\
\text { school }\end{array}$ & 2.62 & 0.60 & Medium \\
\hline $\begin{array}{l}\text { Your school principals attach great importance to } \\
\text { innovation in the field of sport }\end{array}$ & 3.21 & 0.49 & Medium \\
\hline $\begin{array}{l}\text { Your school principals attach great importance to } \\
\text { innovation in the field of institutional }\end{array}$ & 3.25 & 0.43 & Medium \\
\hline $\begin{array}{l}\text { Your school principals attach great importance to } \\
\text { innovation in the field of school culture }\end{array}$ & 3.15 & 0.62 & Medium \\
\hline Total & 3.09 & 0.51 & Medium \\
\hline
\end{tabular}

From the research data obtained showed that the principal's role in innovation was at high stage (mean $=$ 3.25), but the form of the innovation field of academic achievement (mean $=2.62)$, sport (mean $=3.21)$, institutional $(3: 25)$ and school culture (mean $=3.15$ ) at medium stages.

Based on the findings of this study indicated that the innovations made by the principal at the senior high school in Jambi city as overall was sufficient to realize a superior and innovative school.

\section{The Effect of School's Principal Leadership Style against Senior High School Innovation in Jambi city}

This section described research results by using Pearson correlation analysis about the leadership style of the principal of the ten styles of school leadership. Acquired these results were used to answer/prove the answer to the hypothesis $\mathrm{HO}$ can be expressed as described in table 6.

Table 6. The Effect of School's Leadership Style against Senior High School Innovation in Jambi City

\begin{tabular}{lccc}
\hline \multirow{2}{*}{ Leadership styles } & Corelation & Hypothesis (Sig.) & $\begin{array}{c}\text { Interpretation } \\
\text { (Hypothesis) }\end{array}$ \\
\cline { 2 - 4 } & 0.20 & $(0.25)$ & be accepted \\
\hline 1) Participative & $-0,18$ & 0.30 & be accepted \\
2) Laissez Faire & $-0,24$ & 0,17 & be accepted \\
3) Autoritaran & $-0,01$ & 0,93 & be accepted \\
4) Demokratic & & &
\end{tabular}




\begin{tabular}{lccc}
\hline & \multicolumn{3}{c}{ The Effect School's Leadership Style } \\
\cline { 2 - 4 } 5) Charismatic & $-0,01$ & 0.93 & be accepted \\
6) Transformational & $-0,30$ & 0,08 & be accepted \\
7) Situational & $-0,09$ & 0,62 & be accepted \\
8) Trust & 0,14 & 0,44 & be accepted \\
9) Grid & 0,02 & 0,91 & be accepted \\
10) Three-dimention & $-0,10$ & 0,58 & be accepted \\
\hline df $=(n-2) ; n=$ respondents; & & \\
$\rho>0.05(\dot{a})=$ hypothesis is rejected & & \\
$\rho>0.05(\dot{a})=$ hypothesis is accepted &
\end{tabular}

Based on Pearson correlation analysis in table 6 showed that the influence of the principal's leadership style of participative leadership style to the innovation of school was at a significant stage and correlation indicates a positive direction $(r=0: 20, \rho>0.05)$. Therefore, there was a significant relationship between participative leadership style of the principal of the senior high school innovation in Jambi city. This showed that the hypothesis was accepted (sig.0.25). In other words, the hypothesis stated that there was an influence between participative leadership style of school principal at senior high school innovation in Jambi city is proven.

Pearson correlation analysis based on table 6 showed that the influence of the laissez faire leadership style of the principal to the school innovation are at significant stages, but it showed the direction that the negative correlation $(r=-$ $0.18, \rho>0.05$ ). Therefore, there was no significant relationship between laissez faire leadership style of the principal to the senior high school innovation in Jambi city. This showed that the hypothesis was rejected $(r=-0.18 /$ sig.0.30). In other words, the hypothesis stated that there was an influence between laissez faire leadership style to school innovation in Jambi city is not proven.
Pearson correlation analysis based on table 6 showed that the influence of the principal's leadership style of an authoritarian leadership style to the school innovation were at significant stages, but it shows the direction that the negative correlation ( $r=-0.24, \rho>0.05)$. Therefore, there was no significant relationship between the authoritarian leadership style of the principal to school innovation in Jambi city. This showed that the hypothesis was rejected $(r=-0.24 /$ sig.0.17). In other words, the hypothesis stated that there was an influence between the authoritarian leadership style of principal to school innovation in Jambi city was not proven.

Pearson correlation analysis based on table 6 showed that the influence of the democratic leadership style of the principal to the school innovation were at significant stages, but it showed the direction that the negative correlation $(r=-$ $0.01, \rho>0.05)$. Therefore, there was no significant relationship between democratic leadership styles of the principal for school innovation in Jambi city. This showed that the hypothesis was rejected $(r=-0.01 /$ sig.0.93). In other words, the hypothesis states that there was an influence between the democratic leadership style of principal to school innovation in Jambi city was not proven. 
Pearson correlation analysis based on table 6 showed that the influence of charismatic leadership style to the school innovation were at significant stages, but it showed the direction that the negative correlation ( $r=-0.01, \rho>0.05)$. Therefore, there was no significant relationship between charismatic leadership style of the principal for school innovation in Jambi city. This shows that the hypothesis was rejected $(r=-0.01 /$ sig.0.93). In other words, the hypothesis stated that there was an influence between charismatic leadership style of school principal to school innovation in Jambi city was not proven.

Pearson correlation analysis based on table 6 showed that the influence of transformational leadership style to the school innovation were at significant stages, but it showed the direction that the negative correlation $(r=-0.30, \rho>0.05)$. Therefore, there was no significant relationship between transformational leadership style of the principal for school innovation in Jambi city. This showed that the hypothesis was rejected $(r=-0.30 /$ sig.0.08). In other words, the hypothesis stated that there was an influence between transformational leadership style of the principal to school innovation in Jambi city was not proven.

Pearson correlation analysis based on table 6 showed that the influence of situational leadership style to the school innovation were at significant stages, but it showed the direction that the negative correlation ( $r=-0.09, \rho>0.05)$. Therefore, there was no significant relationship between situational leadership style of the principal for school innovation in Jambi city. This showed that the hypothesis was rejected ( $r=-0.09 /$ sig.0.62). In other words, the hypothesis stated that there was an influence between situational leadership style of the principal for school innovation in Jambi city was not proven.
Pearson correlation analysis based on table 6 showed that the influence of the trust leadership style of the principal towards innovation school were at a significant stage and correlation indicated a positive direction ( $r=0.14 \rho>0.05)$. Therefore, there was a significant relationship between the trust leadership style of the principal to school innovation in Jambi city. This showed that the hypothesis was accepted $(r=0.14 /$ sig.0.44). In other words, the hypothesis stated that there was an influence between trust leadership style to school innovation in Jambi city was proven.

Pearson correlation analysis based on table 6 showed that the influence of grid leadership style for school innovation was at the stage of a significant and positive correlation indicated the direction $(r=0: 02, \rho>0.05)$. Therefore, there was a significant relationship between principal's grid leadership style for school innovation in Jambi city. This showed that the hypothesis was accepted $(r=0.02$ / sig.0.91). In other words, the hypothesis stated that there was an influence between principal's grid leadership style for school innovation in Jambi city was proven.

Besides that, Pearson correlation analysis based on table 6 showed that the influence of three-dimensional leadership style for school innovation were at significant stages, but it showed the direction in the negative correlation $(r=$ $0.10, \rho>0.05$ ). Therefore, there was no significant relationship between threedimensional leadership styles for school innovation in Jambi city. This showed that the hypothesis was rejected $(r=-0.10 /$ sig.0.58). In other words, the hypothesis stated that there was an influence between three-dimensional leadership styles for schools innovation in Jambi city was not proven. 


\section{CONCLUSION AND ECOMMENDATION}

From research conducted can be summarized as follows: 1) Principal's leadership style who practiced in senior high school in Jambi city by overall were at high stage (mean $=3.87)$. However, it was found that the implementation of trust leadership style by overall were at a very high stage $($ mean $=4.36)$, whereas the authoritarian leadership style by overall were at medium stage (mean $=$ 2.73), which can be described in table 7 below:

Table 7. Principal's leadership style in senior high school in Jambi city by overall

\begin{tabular}{lccc}
\hline \multirow{2}{*}{ Leadership Styles } & \multicolumn{3}{c}{ Senior High School } \\
\cline { 2 - 4 } & Mean & SD & Interpretation \\
\hline 1) Participative & 4.19 & 0.69 & High \\
2) Laissez Faire & 3.46 & 0.97 & High \\
3) Autoritaran & 2.73 & 1.13 & Medium \\
4) Demokratic & 4.19 & 0.78 & High \\
5) Charismatic & 4.19 & 0.79 & High \\
6) Transformational & 4.18 & 0.69 & High \\
7) Situational & 3.90 & 0.73 & High \\
8) Trust & 4.36 & 0.58 & Very High \\
9) Grid & 4.06 & 0.65 & High \\
10) Three-Dimention & 3.48 & 0.83 & High \\
\hline \multicolumn{1}{r}{ Total } & 3.87 & 0.78 & High \\
\hline
\end{tabular}

$\mathrm{SD}=$ Standard deviation

In table 7, the findings indicate that the ten (10) school principal's leadership styles as mentioned above have been practiced by principals of senior high school in Jambi city, and it has been practised at very high stage especially for trust leadership style.

\section{Innovation happens in senior high school in Jambi city during this time}

Based on the research conducted on the innovation that occured in senior high school in Jambi, the results obtained can be concluded that the innovation that occured at senior high school in Jambi city at the stage of medium (mean $=3.09$ ). From the research data obtained showed that the principal's role in innovation was at high stage $($ mean $=3.25)$, but the form of innovations implemented in the areas of academic achievement (mean $=2.62)$, sport $($ mean $=3.21)$, institutional $($ mean $=$ $3.25)$, and the school culture (mean $=3.15$ ) are at medium stage. Based on the findings of this study indicated that the innovations had made by the principal at senior high school in Jambi city as a whole have not been adequate to achieve superior and innovative school.

\section{Significant Influence between Principal's Leadership Style to Senior High School Innovation in Jambi city}

Based on the research findings through Pearson correlation analysis showed that out of ten (10) school leadership style which tested showed that only participative leadership style 
(sig.0.25), trust leadership style (sig.0.44), and grid leadership style (sig.0.91) which hypothesis were accepted (proven). While other styles of leadership (1) laissez Faire, 2) authoritarian, 3) democratic, 4) charismatic, 5) transformational, 6) situational, and 7) three-dimensional) were not accepted (proven) and even have negative relationship.

When connected to the third research question mentioned above, it can be concluded that the principal has conducted leadership style, and was not directed to innovate school. This was evidenced by the results of studies showed that the innovation school was not sufficient to be an innovative school that was characterized by significant influence of the principal's leadership style only three styles have positive relationships, beside that were in negative.

Based on the findings there are some things that can be recommended for the improvement of leadership styles, they are: 1) the need for reorientation conducted leadership style that leads to innovation school in order to improve at school, especially at senior high school in Jambi city, 2) the need for leadership (principals) to provide guidance continuously on the relevance, access, forms and media to innovate with the school principal that gives greater space to the schools and principals to develop school innovation, 3) the need continuously to be fostered information about innovations planned by the school to be known leaders, teachers and students, and the community.

\section{REFERENCES}

Mangkunegara, A. P. (2011). Perencanaan dan Pengembangan Sumber Daya Manusia. Bandung: Refika Aditama.

Piaw, C. Y. (2006). Kaedah Penyelidikan
Buku 1. Malaysia: McGraw Hill (Malaysia) Sdn. Bhd.

Kerlinger, F. M. (1998). Asas Penelitian Behavior. Yogyakarta: Gajah Mada University Press.

Getol, G. (2012). Management Miracle Series Accepted Leader. Jakarta: Elex Media Komputindo.

Harris, Lown, \& Presscott, W. (Ed). (1978). Curriculum Innovation, London: The Open University, in Lias Hasibuan. 2004. Melejitkan Mutu Pendidikan: Refleksi, Relevansi, dan Rekonstruksi Kurikulum, Jambi: Sapa Project.

Usman, H. (2009). Manajemen Teori, praktik, dan Riset Pendidikan. Rawamangun: Bumi Aksara.

Creswell, J. W \& Clark, V. L. P. (2007). Designing and Conducting Mixed Methods Research. India: Sage Publications.

Prescott, W., \& Hoyle, E. (1976). Innovation Problems and Possibilities, London: The Open University Press as quoted by Hasibuan. 2004. Melejitkan Mutu Pendidikan: Refleksi, Relevansi dan Konstruksi Kurikulum, Jambi: Sapa Project.

Rogers, E. M. (1983). Diffusion of Innovation, New York: The Free Press, in Lias Hasibuan. 2004. Melejitkan Mutu Pendidikan: Refleksi, Relevansi, dan Rekonstruksi Kurikulum, Jambi: Sapa Project.

Muhidin, S. A. \& Abdurrahman, M. (2007). Analisis Korelasi, Regresi dan Jalur. Bandung: Pustaka Setia.

Samsu. (2014). Manajemen dan Kepemimpinan Pendidikan. Jambi: Pusaka Jambi.

Syafaruddin. (2010). Kepemimpinan Pendidikan. Jakarta: Ciputat Press.

Putra, T. A. E. (2009). Kepemimpinan, Globalisasi dan Keperawatan. 
Jember: Universitas Jember.

Rivai, J \& Murni, S. (2009). Education Management Analisis Teori dan Praktik. Jakarta: Raja Grafindo.

Wahyudi. (2009). Kepemimpinan Kepala Sekolah dalam organisasi Pembelajar. Bandung: Afabeta. 